\title{
Moderating role of self-congruence: Impact of brand personality on Brand attachment through the Mediating role of Trust
}

\author{
${ }^{1}$ Asma Amjad, ${ }^{1}$ Fiza Amjad, ${ }^{2}$ Khalid Jamil* ${ }^{1}$ Sharjeel Yousaf \\ ${ }_{1}^{1}$ Department of Management Sciences, National Textile University Faisalabad, Pakistan \\ ${ }^{2} \mathrm{GC}$ University, Faisalabad, Pakistan \\ Asma_amjad1@hotmail.com, Fiza.amjad1@hotmail.com, \\ khalidjamil29@yahoo.com, sharjeel.wahala@gmail.com
}

\begin{abstract}
Increasingly companies are focused on searching for ways to create strong brand connections with consumers. It is illustrated that such connections lead to higher levels of consumer loyalty, which increases companies' financial performance. The main purpose of this study is to explore the impact of brand personality on brand attachment through the mediating role of trust. Also investigate the moderating role of self-congruence on the relationship between brand personality and brand trust. SPSS 23 is used to analyze the data. Data was collected through survey questionnaire technique and snow-ball sampling technique was used for data collection. Analysis reveal Brand personality have significant and positive relationship with brand trust. On the other side trust significantly enhance the brand attachment. While the results prove that self-congruence have significant moderating effect on the relationship between brand personality and brand trust.
\end{abstract}

Keywords: Brand Personality, Brand attachment, Brand trust, Self-congruence

\section{Introduction}

Increasingly companies are focused on searching for ways to create strong brand connections with consumers. It is illustrated that such connections lead to higher levels of consumer loyalty, which increases companies' financial performance (Park \& John, 2010). For example, apparel industry has communicated for years to consumers that using their products will make them more attractive and beautiful, marketing the personality traits of their brand. The congruency between brand's personality traits and customer's personality traits leads to the formation of strong attachment with the brand. Thus, the consumer's selfconcept seems to be growing in importance in marketing messages (Gilmore \& Pine, 2007). Companies create emotional connections with campaigns that focus on consumer's personality (Sirgy, 1982). It has been explored that self-congruence can enhance emotional, attitudinal and behavioral consumer responses to the brand (Grohmann, 2009). The purpose of this research study is to explore the importance of consumer selfcongruence with the brand's personality to form the relations of trust with the brand which ultimately leads to strong attachment with the particular brand. Previous research study on consumer-brand relationship has revealed that understanding the emotional component of such relationships is relevant to both marketers and academics (Fournier, 1998). The feelings that a particular brand generates have the potential to differentiate it from other brands, as consumers usually attach to a limited number of brands (Thomson, MacInnis, \& Whan Park, 2005).

Branded clothing firms are competing to increase their market share and has shifted the conventional clothing interests of people. Pakistan has an advanced textile sector and its economy is successfully growing. In recent years, the increasing use of fashion clothing and emerging market has intrigued foreign as well as local brands to provide services to its customers. Pakistan's apparel sales are expected to reach an estimated $\$ 20$ billion dollar this year, having grown in excess of $10 \%$ over the past 5 years (Pakistan Bureau of Statistics, 2013). The first objective of this research study is to investigate the impact of brand personality on brand trust and consequently its impact on brand attachment. The second objective is to study the moderating role of consumer's self-congruence on brand personality-brand trust relationship, in apparel industry in Faisalabad. The second objective is of great importance for marketing managers.

\section{Literature Review}

Brand personality: Brand personality is defined as a set of human attributes linked to a brand (Aaker, 1997). The brands chosen by the consumers are generally in accordance with their own personalities, that's why 
personality is a useful variable to study the consumer's choice of brands (Keller, 1993). Consumers can think of brands as they are famous historical personalities. Consumers often relate personality of brands with their own self (Fournier, 1998). Demographic factors such as gender, age, social class, etc. also affect the personality ascribed to a brand (Aaker, 1997).For instance the brand personality of Apple is stylish, classy, innovative and intuitive so its user's personality also seems to match with these personality traits. Discernments about brand personality features can be formed by consumer's direct or indirect link with the brand (Plummer, 1985). It is not the brand that shows personality characters but the way the brand is communicated to public through advertisement. Brand personality is an important paradigm for a brand's image and can differentiate a brand in market (Park \& John, 2010). Sometimes consumers select brands whose personality matches with to their ideal self. Correlating human personalities with brands tends consumers to form strong relationships with brands (Swaminathan, Stilley, \& Ahluwalia, 2008). The important element in forming a brand personality is the way it is conveyed to consumers. There are two perceptions in which one can view brand personality, the characterization of brand traits and the emotional association that people have with the brand (Sung \& Yang, 2008). A brand with a strong personality lets consumers to express their own personality traits (Park \& John, 2010).

Trust: Trust is defined as the firm belief in the reliability, truth or ability of someone or something. Trust is constructed on the bases of past experiences. Trust is based on final results. A positive final result enriches trust while negative results will cause the trust to fall. Trust plays an important role in developing and maintaining loyalty towards a brand and in maintaining profitable market share and price elasticity (Chaudhuri \& Holbrook, 2001). Consumer's trust in brand is a variable that creates customers' assurance, mostly high association situation, in which its effect is strong in valuation as a whole satisfaction (DelgadoBallester \& Luis Munuera-Alemán, 2001). Trust is stressed either as a part of association quality or as a factor of affiliation quality. To attain customer trust and for emulating triumph of business, marketers started to embrace the thought of making associations with customers to get their trust (Bennett \& Rundle-Thiele, 2002). Customer Trust generally develops through the following five stages: (1) responsiveness, (2) investigation, (3) enlargement, (4) commitment, and (5) suspension. Customer trust on a certain brand is the determinant of the future purchase intentions of a customer and it is an important factor to maintain a profitable relationship with customer (Lynch \& De Chernatony, 2007).

Self-Congruence: Self-congruence is defined as the analogy between the brand personality and consumer's self-concept. Self-congruence refers to the degree of similarity or gap between an individual's insight of a brand or product and the insight they have of themselves. Consumers prefer the products which are congruent with their self-concept. It is proposed that self-congruence can boost emotional, attitudinal, and behavioral consumer reactions to the brand (Grohmann, 2009). It is proposed that brand personality can be influential in helping consumers express their self-concept and provide a sense of ease to consumers who have found a brand that matches with their self-concept. The consumer will tend to purchase the product whose image is closest to his own. The self-image consumers have, is mostly associated to their purchase behavior (Heath \& Scott, 1998). Congruent Self-image is known by its impact on the inclinations and purchase behavior of individuals, who are in search of synchronization between their self-image and their used product (Pedersen, Nysveen, \& Thorbjørnsen, 2003). Person's personality traits are in coordination with the favored and chosen product, in terms of purposeful features, such as price and quality; therefore, look (physical features) is not only the actual element.

Brand Attachment: Consumers develop and maintain strong relationships with certain brands and these relationships can be of various types. The love for a brand is defined as the degree of fervent attachment that a person has with a particular brand. Consumers love for a brand may include following attributes: 1. Eagerness for a brand 2. Brand attachment 3. Positive appraisal of the brand 4. Positive emotions for the brand and 5. Assertions of love towards the brand. Consumer-Brand relationships are important for the success of a brand. The associations that bonds the brand with the consumer's self are emotional (Swaminathan et al., 2008). The spirits that a brand creates have the prospective to strongly differentiate one brand from another, specifically as consumers habitually fervently attach to only a few brands. The bond that connects consumer with a specific brand includes feelings towards the brand. These feelings includes: passion, love and affiliation (Thomson, 2006). Consumers who experience a strong attachment towards a brand will be more faithful and less price sensitive. While most of the researchers have verified that 
attachment develops and fortifies with the passage of time as consumers have various experiences with the brand. Consumers are expected to form strong emotional links with both product and service brands and say that they love a product or a brand(Lastovicka \& Sirianni, 2011).

Brand Personality associated with Trust: The first hypothesis refers to the relationship between brand personality and consumer's trust on brand. It is argued that the personality traits of a certain brand attract the consumers towards the brand and brand personality is the key to develop consumer's trust on the certain brand. Louis and Lombart (2010) studied the significant influence of brand personality traits on generating consumer's trust on the brand. Khayer, Naeemi, and Ahmadi (2014) in her thesis studied that personality attributes of a brand leads to consumer's satisfaction and trust on the brand which in result leads to consumer's attachment with the brand and ultimately results in consumer's loyalty with the brand.

H1: There is a relationship between brand personality and consumer's trust on the brand.

Trust associated with Brand Attachment: It is assumed that if a customer develops trust on a brand, it ultimately leads to customer's strong emotional attachment with the brand. Consumer's trust on a specific brand leads to consumer's attachment with that brand which is the determinant of future purchase intentions. Fullerton (2005) explored that trust on a brand is the determinant of consumer's attachment with the brand. Garbarino and Jahnson studied that trust and satisfaction plays an important role in developing consumer's attachment with the brand. Trust provides the feelings of security to the customer that leads to the development of attachment with the brand. On the basis of detailed review of literature following hypothesis are developed.

H2: There is a relationship between customer's trust on brand and brand attachment.

Brand Personality associated with Brand Attachment: The third hypothesis refers to the relationship between brand personality and brand attachment. It is stated that brand personality provides the basis for consumer's affiliation towards the brand by characterizing the specific brand. Some researchers argued that personality of a certain brand is the prime determinant of the consumer's attachment with that brand. Mengxia (2007) explored the impact of brand personality on consumers' brand preference and brand attachment. The results show that there is a positive relationship between brand personality and consumers' brand preference and brand attachment. In another research it was investigated that there is a significant relationship between brand personality and consumer's brand attachment.

H3: There is a relationship between brand personality and brand attachment.

Mediating role of Trust: The fourth hypothesis refers to the mediating effect of trust on the relationship of brand personality and brand attachment. Many researchers explore that brand personality leads to trust on brand which ultimately leads to consumer's attachment with the brand so, trust acts a mediator and mediates the relationship of brand personality and brand attachment. Louis and Lombart (2010) explored the influence of personality of a brand on consumer's trust on the brand which leads to the development of consumer's attachment with the brand so, they studied the mediating effect of trust on brand personalitybrand attachment relationship. Personality traits of a brand have strong influence on consumer's mind and these personality traits are the basis to generate trust on the brand and this trust and satisfaction develops a consumer's attachment with the brand.

H4: Trust mediates the relationship of brand personality and brand attachment.

Moderating role of Self Congruence: The fifth hypothesis refers to the moderating effect of self-congruence on the relationship of brand personality and trust. It is assumed that congruence between brand personality and consumer's-self enhances the trust on the brand. Correspondence between individual's personality and brand personality traits play a prominent role in developing trust on the brand which leads to brand attachment (Chaplin \& Roedder John, 2005). If there is no correspondence between the brand personality traits and consumer's personality traits, then trust on the brand will not be developed. Brand personality is the crucial for consumers to express their self-concept, if consumers self matches the brand personality traits then consumer would prefer that brand over other brands.

H5: Self congruence moderates the relationship of brand personality and consumer's trust on the brand. 


\section{Theoretical Framework}

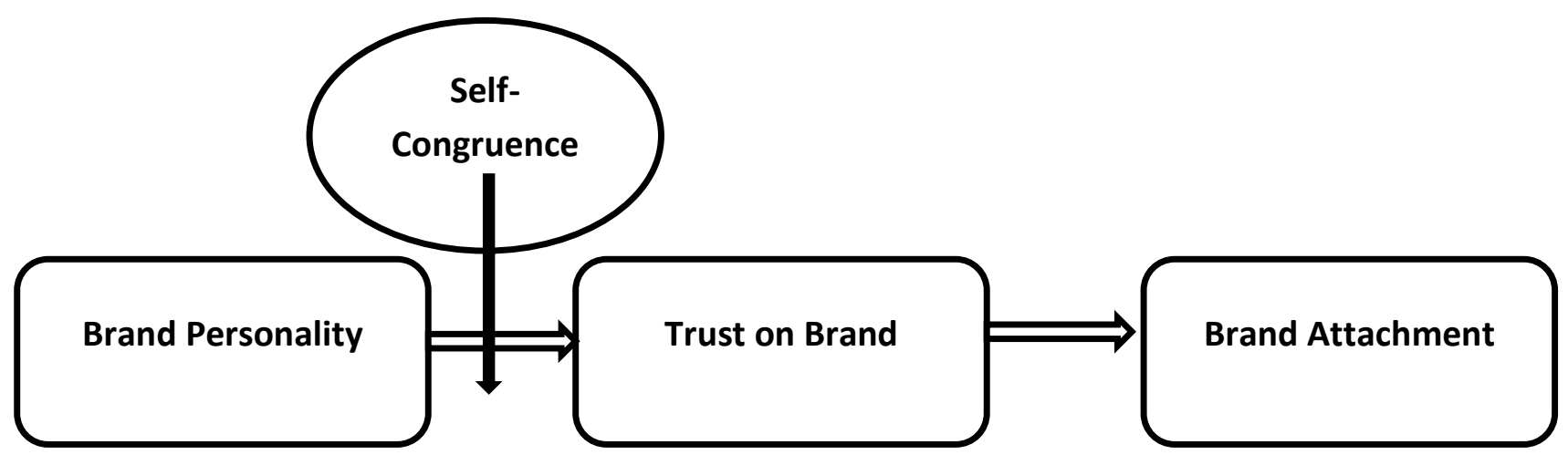

\section{Methodology}

Measures and Sampling Procedure: A self-administered questionnaire was chosen as a research instrument to gather the primary data of brand personality dimensions, self-congruence, and brand trust and brand attachment. The questionnaire was divided into five sections:

- The first section constitutes the demographics of the respondents including users of nine apparel brands and others.

- Brand Personality: In the second section, respondents were asked to show the extent to which personality traits, as proposed by Aaker (1997) describe the apparel brand's personality. The question covers the five dimensions with 42 -items of the brand personality traits. A five-point likert scale ( $1=$ extremely not descriptive to $5=$ extremely descriptive) was used.

- Self-congruence: In the third section, two items were used to determine consumer's self-congruence with brand personality traits as proposed by Kressmann et al. (2006). A five point likert scale was used (1=strongly disagree to $5=$ =strongly agree).

- Brand Attachment: In the fourth section, six items were used to determine consumer's attachment with the brand as proposed by Whan Park, MacInnis, Priester, Eisingerich, and Iacobucci (2010). A five point likert scale was used ( $1=$ strongly disagree to $5=$ strongly agree).

- Brand Trust: In the fifth section, four items were used to determine consumer's trust on brand as proposed by Chaudhuri (2002). A seven point likert scale was used (1=strongly disagree to $7=$ strongly agree).

- A total of 150 questionnaires were distributed to apparel brands users in Faisalabad. The stratified random sampling technique was adopted to increase the accuracy of data. In this research study, the questionnaires were distributed directly to the respondents and the research collected completed questionnaires. It took 2 weeks to distribute and collect the questionnaires.

\section{Results}

Respondent's Profile: The sample of respondents selected for this research study was individual users of apparel brands in Faisalabad. The demographic characteristics of respondents which were included in the questionnaire are: 1. Gender, 2. Income, 3. Age, 4. Qualification, 5. Occupation, 6. Brands. The statistical values such as frequency and percentages of different demographic characteristics of respondents are displayed in the table. 
Table 1: Demographic characteristics of respondents

\begin{tabular}{|c|c|c|c|c|c|}
\hline $\begin{array}{l}\text { Demographic } \\
\text { variables }\end{array}$ & Frequency & $\begin{array}{l}\text { Percentage } \\
\%\end{array}$ & $\begin{array}{l}\text { Demographic } \\
\text { variables }\end{array}$ & Frequency & $\begin{array}{l}\text { Percentage } \\
\%\end{array}$ \\
\hline 1. Gender & & & Bachelor & 54 & 36 \\
\hline Male & 87 & 58 & Masters & 69 & 46 \\
\hline Female & 63 & 42 & Other & 18 & 12 \\
\hline 2. Income & & & 5.0ccupation & & \\
\hline Less than 10,000 & 24 & 16 & Business & 35 & 23.3 \\
\hline $10,000-30,000$ & 74 & 49.3 & Job & 85 & 56.7 \\
\hline $31,000-50,000$ & 33 & 22 & Other & 30 & 20 \\
\hline Above 50,000 & 18 & 12 & 6.Brands & & \\
\hline 3. Age & & & Nishat & 17 & 11.3 \\
\hline Less than 20 & 5 & 3.3 & Maria. B & 15 & 10 \\
\hline $21-25$ & 71 & 47.3 & Gul Ahmed & 20 & 13.3 \\
\hline $26-30$ & 46 & 30.7 & Sana Safinaz & 15 & 10 \\
\hline $31-35$ & 19 & 12.7 & Khaadi & 15 & 10 \\
\hline $36-40$ & 5 & 3.3 & Stone age & 23 & 15.3 \\
\hline Above 40 & 4 & 2.7 & Outfitters & 21 & 14 \\
\hline 4. Qualification & & & Breakout & 13 & 8.7 \\
\hline Intermediate & 8 & 5.3 & Other & 11 & 7.3 \\
\hline
\end{tabular}

According to the statistical values $58 \%$ are male and $42 \%$ are female in this sample. On the basis of income $16 \%$ respondents are of less than 10,000 incomes, $49.3 \%$ respondents have $10,000-30,000$ income, $22 \%$ have $31,000-50,000$ income and $12 \%$ have above 50,000 incomes. On the basis of age $3.3 \%$ respondents are from less than 20 years age group, $47.3 \%$ respondents are from $21-25$ years age group, $30.7 \%$ respondents are from 26-30 years age group, $12.7 \%$ respondents are from 31-35 years age group, 3.3\% respondents are from 36-40 years age group and $2.7 \%$ respondents are from above 40 years age group. On the basis of qualification, $5.3 \%$ respondents were intermediate, $36 \%$ were bachelors, $46 \%$ were masters and $12 \%$ were others. On the basis of occupation, $23.3 \%$ respondents were businessmen, $56.7 \%$ were jobholders and $20 \%$ were others. $11.3 \%$ respondents use Nishat, $10 \%$ use Maria. B, $13.3 \%$ use Gul Ahmed, $10 \%$ use Sana Safinaz, $10 \%$ use Khaadi, $15.3 \%$ use stone age, 14 use outfitters, $8.7 \%$ used breakout and $7.3 \%$ use other brands.

Reliability Analysis: Cronbach alpha coefficient was conducted for checking reliability and internal consistency of measure. Cronbach alpha is a measure of reliability that ranges from 0 to 1 with values .60 to .70 considered the lower limit of acceptability (Hair, Anderson, Tatham, \& William, 1998).

Table 2: Reliability Statistics:

\begin{tabular}{lll}
\hline Variables & Cronbach's Alpha & N of Items \\
\hline Brand Personality & .923 & 42 \\
Self-congruence & .809 & 2 \\
Brand Trust & .898 & 4 \\
Brand Attachment & .883 & 6 \\
\hline
\end{tabular}

The results of cronbach alpha included four variables calculated using different point likert scale. Reliability values of variables show the reliability of data and number of items in each variable scale. The reliability analysis shows that reliability of brand personality scale is .923 , reliability of self-congruence scale is .809 , reliability of brand trust scale is .898 and reliability of brand attachment scale is .883. In this research study, all variables scales show reliability greater than .70 which is very good and acceptable. All the variables are consistent highly reliable in their values.

Correlation Analysis: Descriptive statistics includes arithmetic mean and standard deviation of all variables in which both demographic and study variables are included. Brand personality was measured on 5-point likert scale $(1=$ =xtremely not descriptive to 5 =extremely descriptive), Self-congruence and brand attachment were measured on a 5-point likert scale (1=strongly disagree to strongly agree) and brand trust was 
measured on 7-point likert scale (1=strongly disagree to $7=$ strongly agree). Descriptive statistics and correlation are shown in the following table:

Table 3: (Mean, Standard Deviation, Correlation)

\begin{tabular}{|c|c|c|c|c|c|c|c|c|c|c|c|c|}
\hline & Mean & S.D & 1 & 2 & 3 & 4 & 5 & 6 & 7 & 8 & 9 & 10 \\
\hline 1.Gender & 1.42 & .495 & 1 & & & & & & & & & \\
\hline 2.0ccupation & 1.97 & .660 & $.310^{* *}$ & 1 & & & & & & & & \\
\hline 3.Age & 2.73 & 1.021 & $-.1 .75^{*}$ & $-.362^{* *}$ & 1 & & & & & & & \\
\hline 4.Income & 2.32 & .907 & $-.376^{* *}$ & $-.419^{* *}$ & $.469^{* *}$ & 1 & & & & & & \\
\hline 5.Education & 3.67 & .783 & .069 & -.100 & $.182^{*}$ & $.208^{*}$ & 1 & & & & & \\
\hline 6.Brands & 4.87 & 2.457 & $-.544^{* *}$ & $-.231^{* *}$ & .109 & $.323^{* *}$ & .105 & 1 & & & & \\
\hline $\begin{array}{l}\text { 7.Brand } \\
\text { Personality }\end{array}$ & 4.11 & .417 & -.023 & -.154 & $.305^{* *}$ & $.167^{*}$ & -.040 & .144 & 1 & & & \\
\hline $\begin{array}{l}\text { 8.Self- } \\
\text { congruence }\end{array}$ & 4.55 & .692 & .036 & -.070 & $.275^{* *}$ & .145 & -.019 & .067 & $.715^{* *}$ & 1 & & \\
\hline $\begin{array}{l}\text { 9.Brand } \\
\text { Attachment }\end{array}$ & 4.31 & .632 & .018 & -.142 & $.308^{* *}$ & .126 & -.045 & .048 & $.761^{* *}$ & $.668^{* *}$ & 1 & \\
\hline $\begin{array}{l}\text { 10.Brand } \\
\text { Trust }\end{array}$ & 6.22 & .942 & .074 & -.088 & $.201^{*}$ & .143 & -.086 & .40 & $.722^{* *}$ & $.719^{* *}$ & $.710^{* *}$ & 1 \\
\hline
\end{tabular}

** Correlation is significant at the 0.01 level (2-tailed).

*Correlation is significant at the 0.05 level (2-tailed).

Correlation analysis is used to measure the strength of linear relationship among two variables. Correlation value range from -1 to +1 , closer to -1 correlation is negative and strong and closer to +1 correlation is positive and strong (Hair, Black, Babin, Anderson, \& Tatham, 2010). In the above table, Pearson correlation coefficients are calculated to measure the relationship among all variables. The relationship may be negative or positive and significant or insignificant. Correlation results of all variables support all research hypotheses. It is explored that there is positive and linear relationship among all variables. The level of significance ( $\mathrm{p}=\mathrm{value})$ is significant at $(\mathrm{p}<0.01){ }^{* *}$ Level $(2$ tailed). Results shows brand personality have positive and significant relationship with brand trust $(r=.722, \mathrm{p}<0.01)$ that explored brand personality and brand trust are positively linked with each other. Correlation results explore that brand personality and brand trust have significant relationship with each other which also support study hypothesis that (H1: There is relationship between brand personality and customer trust). Results also reveal that brand personality has positive and significant relationship with brand attachment $(\mathrm{r}=.668, \mathrm{p}<0.01)$. Results indicate there is positive relationship between brand personality and brand attachment that also support research hypothesis that (H2: There is relationship between brand trust and brand attachment). Brand personality has positive and significant relationship with brand attachment $(\mathrm{r}=.761, \mathrm{p}<0.01)$. These two variables are significantly interlinked with each other. That also support research hypothesis that (H3: There is relationship between brand personality and brand attachment).

Regression results of brand attachment as dependent variable and brand personality as independent variable shows positive and significant relation between these two variables at $(\mathrm{p}<.001)$ significance. Regression results of brand trust as dependent variable and brand personality as independent variable shows significant relation between these two variables at $(\mathrm{p}<.001)$ significance. Regression results of brand trust as independent variable and brand attachment as dependent variable shows significant relation between these two variables at $(\mathrm{p}<.001)$ significance. 
Table 4: Regression Analysis

\begin{tabular}{llll}
\hline \multirow{2}{*}{$\begin{array}{l}\text { Brand Attachment } \\
\text { Brand }\end{array}$} & R square & Significance & Beta \\
\cline { 2 - 4 } Personality & .580 & .000 & .761 \\
\hline $\begin{array}{l}\text { Brand Trust } \\
\text { Brand }\end{array}$ & R square & Significance & Beta \\
\cline { 2 - 4 } Personality & .522 & .000 & .722 \\
\hline $\begin{array}{l}\text { Brand Attachment } \\
\text { Brand }\end{array}$ & R square & Sigma & Beta \\
\cline { 2 - 4 } Trust & .504 & .000 & .710 \\
\hline
\end{tabular}

Mediation Analysis: This study is a first attempt to examine the mediating effect of brand trust between brand personality and brand attachment for apparel brands. In this part of study hypothesis four stated that $\mathrm{H} 4$ : Brand trust mediates the relationship of brand personality and brand attachment. Regression technique was used to test this hypothesis which was recommended by (Baron \& Kenny, 1986). According to (Baron \& Kenny, 1986), following condition should be fulfilled. (1) The relationship between independent variable and mediating variable should be significant; (2) the relationship between mediating variable and dependent variable should also be significant. (3) The relationship between independent and dependent variables should also be significant. When these three conditions are fulfilled then researcher goes for further analysis. Perfect mediation is when the independent variable has direct effect on dependent variable i.e. $\left(\Delta \mathrm{R}^{2}=.00\right)$ and independent variable should also have $(\beta \neq$ sig).

Table 5: Mediation effect

\begin{tabular}{llll}
\hline & \multicolumn{2}{l}{ Brand Attachment } \\
R square & R square change & Beta \\
\hline $\begin{array}{l}\text { Brand } \\
\begin{array}{l}\text { Personality } \\
\text { Brand } \\
\text { Trust }\end{array}\end{array}$ & .580 & .580 & .520 \\
& .633 & .054 & .335
\end{tabular}

Regression results shows that brand trust partially mediates the relationship of brand personality and brand attachment as change in $\mathrm{R}$ square is not perfectly equal to zero ( $\mathrm{R}$ square change=.357) ( $\mathrm{R}$ square change $\neq .00$ ).

Table 6: Moderator Analysis

\begin{tabular}{llll}
\hline & \multicolumn{2}{l}{ Brand Attachment } \\
& R square & R square change & Significance \\
\hline $\begin{array}{l}\text { Brand } \\
\begin{array}{l}\text { Personality } \\
\text { Self- } \\
\text { congruence }\end{array}\end{array}$ & .611 & .611 & .000 \\
\hline
\end{tabular}

Moderation analysis results show that self-congruence strongly moderates the relationship of brand personality and brand attachment as $(\mathrm{p}<.05)$ and ( $\mathrm{R}$ square change $<.01)$. These two conditions fulfill the moderation analysis.

Discussion: Brand personality has a relationship with brand trust. The Louis and Lombart (2010)discussed that the significant influence of brand personality traits on generating consumer's trust on the brand. Khayer et al. (2014) in her thesis studied that personality attributes of a brand leads to consumer's satisfaction and trust on the brand which in result leads to consumer's attachment with the brand and ultimately results in consumer's loyalty with the brand. These studies support H1. Second hypothesis discuss that brand trust have relationship with brand attachment. Fullerton (2005) explored that trust on a brand is the determinant of consumer's attachment with the brand. Garbarino and Jahnson studied that trust and satisfaction plays an important role in developing consumer's attachment with the brand. Trust provides the feelings of security to 
the customer that leads to the development of attachment with the brand. These studies supported H2. Brand personality has a relationship with brand attachment. Studies of Mengxia (2007) explored the impact of brand personality on consumers' brand preference and brand attachment. The results show that there is a positive relationship between brand personality and consumers' brand preference and brand attachment. In another research it was investigated that there is a significant relationship between brand personality and consumer's brand attachment. $\mathrm{H} 3$ is supported by the above studies. The mediating role of brand trust between brand personality and brand attachment is positive. Louis and Lombart (2010) explored the influence of personality of a brand on consumer's trust on the brand which leads to the development of consumer's attachment with the brand so, they studied the mediating effect of trust on brand personalitybrand attachment relationship. Personality traits of a brand have strong influence on consumer's mind and these personality traits are the basis to generate trust on the brand and this trust and satisfaction develops a consumer's attachment with the brand. H4 is supported by previous studies. Moderating role of selfcongruence is also supported by some studies. It is assumed that congruence between brand personality and consumer's-self enhances the trust on the brand Grohmann (2009). Correspondence between individual's personality and brand personality traits play a prominent role in developing trust on the brand which leads to brand attachment (Chaplin \& Roedder John, 2005).

\section{Conclusion}

This research study examined the impact of dimensions of brand personality traits on brand attachment: the mediating role of brand trust. This is a study of brands of apparel industry in Faisalabad. The main objectives of this study are to discover the mediating role of brand trust between brand personality and brand attachment. And to find out the moderating effect of self-congruence on the relationship of brand personality and customer trust. For this study, researcher was considered only about apparel industry brands. Following categories of brands were selected: 1) Nishat, 2) Maria. B 3) Gul Ahmed, 4) Sana Safinaz, 5) Khaadi, 6) Stone age, 7) Outfitters, 8) Breakout and others. The apparel industry in Pakistan is contributing a lot in economy, it is a highly important segment that plays a pivotal role in financial sector of Pakistan. Due to high level of competition in apparel sector, brands have to be more innovative and more aggressive in developing their product in order to meet the demand of target customer, and to develop trust and customer's attachment with brand. The primary data collection method was used in this study; a self-administered questionnaire was used for collecting data from 150customers of different brands. Sample size is based on convenient sampling technique. Brand personality was an independent variable, Brand attachment is a dependent variable, and brand trust is mediating variable according to theoretical framework of this study. All these variables were measured by using different point likert scale which was adopted from previous literature. The Statistical techniques descriptive analysis, Cronbach alpha, correlation analysis, and regression analysis had been used to explore the relationship between variables. Results showed that there is significant and positive linear relationship among all study variables, the level of significant $(\mathrm{p}<$ value) for all study variables is significant at $(\mathrm{p}=0.01)^{* *}$ level 2 tailed. Results explore that brand personality have positive and significant impact on brand trust and brand attachment.

Practical Implications of this Research Study: The findings of this research have several practical implications. The apparel brands like other business having main purpose to make profit improve performance and remain successful, which is not possible without the trust attachment of customers with a particular brand. The brand personality positively and significantly impacts on customer trust and customer's attachment with brand. The findings of this research study will be helpful for apparel sector in order to improve and develop their brand's personality with aim to develop customer's trust on brand which ultimately leads to brand attachment. Furthermore, consumer's self-congruence plays a moderating role and impacts the relationship of brand personality and brand trust. The important and theoretical implication of this study is the mediating effect of brand trust that increases the customer's attachment with the brand and also contributed in literature. There is not any study previously (according to researcher knowledge) about the moderating effect of consumer's self-congruence on the relation of brand personality and brans trust. The research findings will significantly contribute in both practical and theories in future. 


\section{Limitations and Future Implications}

- In this research study data is collected from a small sample size of 150 respondents' base on convenient sampling and respondent were selected randomly. Future study could be conducted by using large sample size and more effective sampling techniques that lead to generalization. This research was only conducted on one sector (apparel sector) same model could also be implemented on other sectors like restaurants industry, footwear industry, etc.

- This research is only conducted for a specific region, for a specific city i.e. Faisalabad. The future direction for this research study is that it could be applied in other cities of Pakistan or all over Pakistan.

- This study also examines the brand personality as one variable rather than working on all dimensions of brand personality individually. Future studies could be conducted by working on separate dimensions of brand personality.

- In this research study data was collected through questionnaire manually. Next research studies could be improved if web based survey will be conducted.

- This research only predicts that brand trust mediates the relationship between brand personality and brand attachment. The researcher also believed that there could be other number of variables that can also mediate this relationship.

\section{References}

Aaker, J. L. (1997). Dimensions of brand personality. Journal of Marketing Research, 3, 347-356.

Baron, R. M. \& Kenny, D. A. (1986). The moderator-mediator variable distinction in social psychological research: Conceptual, strategic, and statistical considerations. Journal of personality and social psychology, 51(6), 1173-1182.

Bennett, R. \& Rundle-Thiele, S. (2002). A comparison of attitudinal loyalty measurement approaches. Journal of brand management, 9(3), 193-209.

Chaplin, L. N. \& Roedder John, D. (2005). The development of self-brand connections in children and adolescents. Journal of Consumer Research, 32(1), 119-129.

Chaudhuri, A. (2002). How brand reputation affects the advertising-brand equity link. Journal of advertising research, 42(3), 33-43.

Chaudhuri, A. \& Holbrook, M. B. (2001). The chain of effects from brand trust and brand affect to brand performance: the role of brand loyalty. Journal of Marketing, 65(2), 81-93.

Delgado-Ballester, E. \& Luis Munuera-Alemán, J. (2001). Brand trust in the context of consumer loyalty. European Journal of Marketing, 35(11/12), 1238-1258.

Fournier, S. (1998). Consumers and their brands: Developing relationship theory in consumer research. Journal of Consumer Research, 24(4), 343-373.

Fullerton, G. (2005). The impact of brand commitment on loyalty to retail service brands. Canadian Journal of Administrative Sciences/Revue Canadienne des Sciences de l'Administration, 22(2), 97-110.

Gilmore, J. H. \& Pine, B. J. (2007). Authenticity: What consumers really want: Harvard Business Press.

Grohmann, B. (2009). Gender dimensions of brand personality. Journal of Marketing Research, 46(1), 105119.

Hair, J. F., Black, W. C., Babin, B. J., Anderson, R. E. \& Tatham, R. L. (2010). Multivariate data analysis (Vol. 7): Prentice Hall Upper Saddle River, NJ.

Heath, A. P. \& Scott, D. (1998). The self-concept and image congruence hypothesis: an empirical evaluation in the motor vehicle market. European Journal of Marketing, 32(11/12), 1110-1123.

Keller, K. L. (1993). Conceptualizing, measuring, and managing customer-based brand equity. The Journal of Marketing, 2, 1-22.

Khayer, A., Naeemi, E. A. \& Ahmadi, K. (2014). The Effect of Ethical Aspects of Brand on Increase of Corporates Reputation among Consumers in Shiraz. Kuwait Chapter of the Arabian Journal of Business and Management Review, 3(6A), 17.

Kressmann, F., Sirgy, M. J., Herrmann, A., Huber, F., Huber, S. \& Lee, D. J. (2006). Direct and indirect effects of self-image congruence on brand loyalty. Journal of Business research, 59(9), 955-964.

Lastovicka, J. L. \& Sirianni, N. J. (2011). Truly, madly, deeply: Consumers in the throes of material possession love. Journal of Consumer Research, 38(2), 323-342. 
Louis, D. \& Lombart, C. (2010). Impact of brand personality on three major relational consequences (trust, attachment, and commitment to the brand). Journal of product \& brand management, 19(2), 114-130.

Lynch, J. \& De Chernatony, L. (2007). Winning hearts and minds: business-to-business branding and the role of the salesperson. Journal of marketing management, 23(1-2), 123-135.

Mengxia, Z. (2007). Impact of brand personality on PALI: a comparative research between two different brands. International Management Review, 3(3), 36.

Park, J. K. \& John, D. R. (2010). Got to get you into my life: Do brand personalities rub off on consumers? Journal of Consumer Research, 37(4), 655-669.

Pedersen, P. E., Nysveen, H. \& Thorbjørnsen, H. (2003). Identity expression in the adoption of mobile services: The case of multimedia messaging services.

Plummer, J. T. (1985). Brand personality: A strategic concept for multinational advertising. Paper presented at the Marketing educators' conference.

Sirgy, M. J. (1982). Self-concept in consumer behavior: A critical review. Journal of Consumer Research, 9(3), 287-300.

Sung, M. \& Yang, S. U. (2008). Toward the model of university image: The influence of brand personality, external prestige, and reputation. Journal of public relations research, 20(4), 357-376.

Swaminathan, V., Stilley, K. M. \& Ahluwalia, R. (2008). When brand personality matters: The moderating role of attachment styles. Journal of Consumer Research, 35(6), 985-1002.

Thomson, M. (2006). Human brands: Investigating antecedents to consumers' strong attachments to celebrities. Journal of Marketing, 70(3), 104-119.

Thomson, M., MacInnis, D. J. \& Whan Park, C. (2005). The ties that bind: Measuring the strength of consumers' emotional attachments to brands. Journal of consumer psychology, 15(1), 77-91.

Whan Park, C., MacInnis, D. J., Priester, J., Eisingerich, A. B. \& Iacobucci, D. (2010). Brand attachment and brand attitude strength: Conceptual and empirical differentiation of two critical brand equity drivers. Journal of Marketing, 74(6), 1-17. 